\title{
Delayed inflammatory mRNA and protein expression after spinal cord injury
}

Kimberly R Byrnes ${ }^{1,2^{*}}$, Patricia M Washington', Susan M Knoblach ${ }^{3,4}$, Eric Hoffman ${ }^{3,4}$ and Alan I Faden ${ }^{1,5,6}$

\begin{abstract}
Background: Spinal cord injury (SCl) induces secondary tissue damage that is associated with inflammation. We have previously demonstrated that inflammation-related gene expression after SCl occurs in two waves - an initial cluster that is acutely and transiently up-regulated within 24 hours, and a more delayed cluster that peaks between 72 hours and 7 days. Here we extend the microarray analysis of these gene clusters up to 6 months post-SCl.

Methods: Adult male rats were subjected to mild, moderate or severe spinal cord contusion injury at T9 using a well-characterized weight-drop model. Tissue from the lesion epicenter was obtained 4 hours, 24 hours, 7 days, 28 days, 3 months or 6 months post-injury and processed for microarray analysis and protein expression.

Results: Anchor gene analysis using $\mathrm{C1qB}$ revealed a cluster of genes that showed elevated expression through 6 months post-injury, including galectin-3, p22 $2^{\mathrm{PHOX}}, \mathrm{gp} 91^{\mathrm{PHOX}}, \mathrm{CD} 53$ and progranulin. The expression of these genes occurred primarily in microglia/macrophage cells and was confirmed at the protein level using both immunohistochemistry and western blotting. As p22 ${ }^{\mathrm{PHOX}}$ and $\mathrm{gp} 91^{\mathrm{PHOX}}$ are components of the NADPH oxidase enzyme, enzymatic activity and its role in SCI were assessed and NADPH oxidase activity was found to be significantly up-regulated through 6 months post-injury. Further, treating rats with the nonspecific, irreversible NADPH oxidase inhibitor diphenylene iodinium (DPI) reduced both lesion volume and expression of chronic gene cluster proteins one month after trauma.
\end{abstract}

Conclusions: These data demonstrate that inflammation-related genes are chronically up-regulated after $\mathrm{SCl}$ and may contribute to further tissue loss.

Keywords: Microglia, Chronic, Inflammation, Galectin-3, Mac-2, Microarray, NADPH oxidase, DPI

\section{Background}

Spinal cord injury (SCI) is followed by delayed secondary damage that occurs for days, weeks and even months following the initial insult $[1,2]$. Inflammation, including the activation and migration of microglia and macrophages, plays a significant role in this secondary injury [3-9]. Microglia are the primary immune response cells in the CNS [10] and can be activated by a number of pro-inflammatory cytokines and chemokines or other alterations in the CNS environment [11,12]. Microglia respond quickly, within minutes, to environmental changes such as increases in ATP concentration or injury [13]. After SCI, microglia are the dominant

\footnotetext{
* Correspondence: kbyrnes@usuhs.mil

'Department of Neuroscience, Georgetown University Medical Center, Reservoir Rd, NW, Washington, DC (20057), USA Full list of author information is available at the end of the article
}

monocyte occupying the injury site through 3 days postinjury, after which macrophages begin to invade the lesion site [14]; immunocytochemically, the two cell types are indistinguishable.

We have shown that genes associated with inflammation, including those expressed primarily by microglia/ macrophages, are strongly up-regulated immediately after injury and remain up-regulated for at least 7 days [15]. Further, Popovich et al. [16] has demonstrated that areas of blood-spinal cord barrier permeability 14 to 28 days post-injury are associated with OX42 (microglia/ macrophage) labeling, suggesting extensive monocytic activity at delayed time points post-injury.

Our earlier work investigated the delayed up-regulation of expression of selected inflammation-related genes up to 7 days after SCI [15]; these genes included $\mathrm{C} 1 \mathrm{qB}, \mathrm{CD} 53$, galectin-3 and $\mathrm{p} 22^{\mathrm{PHOX}}$, among others.
Ciomed Central 
While these genes have not been studied extensively in $\mathrm{SCI}$, they have all been shown to play important roles in post-injury inflammation. For example, $\mathrm{p} 22^{\mathrm{PHOX}}$ is a core component of the NADPH oxidase enzyme, which plays a key role in the production of reactive oxygen species (ROS). This enzyme is composed of 4 cytosolic subunits ( $\mathrm{p} 40^{\text {PHOX }}, \mathrm{p} 47^{\text {PHOX }}, \mathrm{p} 67^{\text {PHOX }}$ and GTP-binding protein $\mathrm{p} 21-\mathrm{Rac} 1)$ and 2 membrane subunits (gp91 ${ }^{\text {PHOX }}$ and $\mathrm{p} 22^{\mathrm{PHOX}}$ ) [17]. ROS and their derivatives can have severe cytotoxic effects $[18,19]$, including induction of pro-inflammatory cytokine expression via MAPK and $\mathrm{NF} \kappa \mathrm{B}$ signaling [20]. Reduction of NADPH oxidase activity can mitigate the microglial response and reduce neuronal cell death [15,21-25]. Diphenylene iodonium (DPI), a nonspecific, irreversible inhibitor of NADPH oxidase, operates by modifying the heme component of NADPH oxidase, disrupting the ability of the enzyme to generate ROS [26,27]. DPI blocks NF $\kappa \mathrm{B}$ activation in microglia, which reduces iNOS and cytokine production [24]. Inhibition of NADPH oxidase with DPI also impairs peroxynitrite production and suppresses microglial-induced oligodendrocyte precursor cell death [28].

The goal of this work was to examine the chronic expression of microglial-related genes, examining up to 6 months after SCI, and to begin to assess the relationship and function of these proteins, particularly of NADPH oxidase. The characterization of inflammatory gene expression is important for understanding the role of inflammation, including microglial and macrophage activation, in secondary injury for the development of SCI therapeutics.

\section{Methods \\ Spinal Cord Injury}

Contusion SCI was performed in adult male Sprague Dawley rats as previously described [29]. Briefly, rats (275 - $325 \mathrm{~g})$ were anesthetized with sodium pentobarbital $(67 \mathrm{mg} / \mathrm{kg}$, I.P.) and mild, moderate or severe injury was induced using a weight drop method, in which a 10 g weight was dropped from $17.5,30$, or $50 \mathrm{~mm}$, respectively, onto an impounder positioned on the exposed spinal cord at vertebral level T-9. Sham injured animals underwent the same experimental procedures, but received a laminectomy only, without weight drop. All experiments complied fully with the principles set forth in the "Guide for the Care and Use of Laboratory Animals" prepared by the Committee on Care and Use of Laboratory Animals of the Institute of Laboratory Resources, National Research Council (DHEW pub. No. (NIH) $85-23,2985)$ and were approved by the Georgetown University IACUC.

\section{Expression Profiling}

Animals were deeply anesthetized with sodium pentobarbital (100 mg/kg, I.P.) and decapitated 4 hours, 24 hours, 7, 14 and 28 days and 3 or 6 months after injury. A $1 \mathrm{~cm}$ section of the spinal cord centered at the lesion epicenter, T-9, was dissected, and immediately frozen on dry ice. Two naïve controls (rats that did not undergo any surgical procedure) were also included in the analysis.

Expression profiling was performed as described previously [15,30]. Briefly, $7 \mu$ g of total RNA was extracted using TRIzol reagent (Invitrogen, Carlsbad, CA) and used for complementary DNA (cDNA) and biotinylated complementary RNA (cRNA) synthesis. RNA was then hybridized to the Affymetrix rat U34A, B, and C arrays according to the manufacturer's protocol (Affymetrix, Santa Clara, CA). Collectively these chips include approximately 28,000 genes and ESTs. Samples were not combined; each gene chip was dedicated to a single spinal cord sample.

\section{Microarray Quality control}

We employed stringent quality control methods as previously published [31]. Each array fulfilled the following quality control measures: cRNA fold changes between 5 to 10 , scaling factor from $0.3-1.5$, percentage of "present" (P) calls from 40-55\%, average signal intensity levels between 900-1100, housekeeping genes and internal probe set controls showed $>80 \%$ present calls, consistent values and 5'/3' ratios were $<3$.

Experimental normalization, data filtering and statistical analysis on gene expression profiles were generated with the dChip probe-set algorithm and GeneSpring software using a Welch ANOVA t-test $\mathrm{p}$ value $<0.05$ between sham and injured groups.

\section{Pathway Analysis}

The cluster of temporally correlated genes obtained from the microarray was inputted into the GeneGo MetaCore $^{\mathrm{TM}}$ pathway analysis software (St. Joseph, MI). Using the Direct Interactions, Shortest Path, and Transcription Regulation algorithms, connectivity of the gene list was obtained.

\section{Western Blot}

At 28 days and 6 months post-injury, 4 moderate-contusion injured and 2 sham injured rats per time point were anesthetized $(100 \mathrm{mg} / \mathrm{kg}$ sodium pentobarbital, I. P.) and decapitated. A $1 \mathrm{~cm}$ section of the spinal cord (approximately $50 \mathrm{mg}$ of tissue weight) centered at the lesion epicenter, T-9, was dissected, and immediately frozen on dry ice and western blot was performed as described previously [15]. Briefly, tissue was homogenized in RIPA Buffer and centrifuged to isolate protein. Twenty-five $\mu \mathrm{g}$ of protein were run in SDS polyacrylamide gel electrophoresis and blotted onto a nitrocellulose filter. The blot was then probed with antibodies 
against galectin-3 (1:1000; Abcam, Cambridge, MA), progranulin (1:1000; R\&D Systems, Minneapolis, MN), gp91 ${ }^{\text {PHOX }}$ (1:1000; BD Transduction Laboratories, San Jose, CA) and p22 $2^{\text {PHOX }}$ (1:1000; Santa Cruz Biotechnology, Santa Cruz, CA). Immune complexes were detected with appropriate secondary antibodies and chemiluminescence reagents (Pierce, Rockford, IL). $\beta$-actin or GAPDH were used as controls for gel loading and protein transfer. Scion Image Analysis (http://www.scioncorp.com/) was used to assess pixel density of resultant blots to compare between sham-injured and injured spinal cord tissue.

\section{Immunohistochemistry}

At 28 days post-injury, 4 moderate-contusion injured and 2 sham injured rats per time point were anesthetized $(100 \mathrm{mg} / \mathrm{kg}$ sodium pentobarbital, I.P.) and intracardially perfused with $100 \mathrm{ml}$ of $0.9 \%$ saline followed by $300 \mathrm{ml}$ of $10 \%$ buffered formalin. A $1 \mathrm{~cm}$ section of spinal cord centered at the lesion epicenter, T-9, was dissected, post-fixed in $10 \%$ buffered formalin overnight and cryoprotected in $30 \%$ sucrose for 48 hours. Standard fluorescent immunocytochemistry on serial, $20 \mu \mathrm{m}$ thick coronal sections was performed as described previously [15]. Antibodies included NeuN (1:200; Millipore, Billerica, MA), GFAP (1:100; Promega, Madison, WI), Iba-1 (1 $\mu \mathrm{g} / \mathrm{ml}$; Wako, Richmond, VA), C1q (1:100; US Biologicals, Swampscott, MA), galectin-3 $(6 \mu \mathrm{g} / \mathrm{ml})$, p $22^{\text {PHOX }}$ (1:200), progranulin (1:200), and gp91 ${ }^{\text {PHOX }}$ (1:100). Appropriate secondary antibodies linked to FITC or Cy3 fluorophores (Jackson Immunoresearch, West Grove, PA) were incubated with tissue sections for 1 hour at room temperature. Slides were coverslipped using mounting media containing DAPI to counterstain for nuclei (Vector Labs, Burlingame, CA). To ensure accurate and specific staining, negative controls were used in which the primary antibody was not applied to sections from injured tissue, and only staining that labeled cells that were double-labeled with expected cell markers or had expected labeling patterns (i.e., classic microglia morphology) was confirmed as positive labeling. Immunofluorescence was detected using confocal microscopy or an AxioPlan Zeiss Microscopy system (Carl Zeiss, Inc., Thornwood, NY).

Immunofluorescence was detected and quantified in twelve $20 \mu \mathrm{m}$ sections, selected with a random start and consistent interslice distance, using confocal microscopy as described previously [32]. In brief, the proportional area of tissue occupied by immunohistochemically stained cellular profiles within a defined target area (the lesion site and surrounding tissue) was measured using the Scion Image Analysis system using a method modified from Popovich and colleagues [33].

\section{NADPH Oxidase Activity Assay}

At 3 and 6 months post-injury, 4 moderate-contusion injured and 2 sham injured rats per time point were anesthetized $(100 \mathrm{mg} / \mathrm{kg}$ sodium pentobarbital, I.P.) and decapitated. A $1 \mathrm{~cm}$ section of the spinal cord (approximately $50 \mathrm{mg}$ of tissue weight) centered at the lesion epicenter, T-9, was dissected, and immediately frozen on dry ice for NADPH oxidase activity assessment as previously described [34]. Briefly, tissue was homogenized in lysis buffer (50 mM Tris, $0.1 \mathrm{mM}$ EDTA, 0.1 $\mathrm{mM}$ EGTA, $10 \mu \mathrm{g} / \mathrm{ml}$ aprotinin, $10 \mu \mathrm{g} / \mathrm{ml}$ leupeptin, 1 $\mathrm{mM}$ phenylmethylsulfonyl fluoride) and centrifuged at $16,000 \mathrm{G}$ for 15 minutes. The supernatant was then centrifuged at 100,000G for $1 \mathrm{hr}$ for cell fractionation. Forty $\mu \mathrm{g}$ of protein from the membrane fraction was added to lysis buffer and NADPH oxidase buffer, along with DHE and NADPH and the plate was assessed at an emission of $485 \mathrm{~nm}$ and absorption of $590 \mathrm{~nm}$.

\section{NADPH Oxidase Inhibition}

For NADPH oxidase inhibition experiments, a polyethylene catheter (P-100, 1.52 outside diameter) attached to an Alzet mini-osmotic pump (Alzet, Cupertino, CA; Model 2001) was inserted into the intrathecal space at 30 minutes post-injury and advanced toward the lesion site, resting $1-2 \mathrm{~mm}$ below the lesion site, as described previously [35]. The mini-osmotic pump was loaded with either DPI (Sigma, St. Louis, MO; $100 \mu \mathrm{M}$ in 1\% DMSO in saline; $\mathrm{n}=3$ ) or vehicle (1\% DMSO in saline; $\mathrm{n}=3$ ) and administered $1 \mu \mathrm{l}$ of drug (representing 0.1 pmoles/day) or vehicle per hour for 7 days (7 day infusing pump).

\section{MRI Analysis}

At 28 days post-injury, rats underwent magnetic resonance imaging (MRI) using a 7 Tesla $20 \mathrm{~cm}$ bore MRI (Bruker Biospin Billerica, MA). Rats underwent a 2D T2 weighted imaging protocol, in which the field of view was $90 \times 90 \mathrm{~mm}$. The $\mathrm{TR}=3640 \mathrm{msec}, \mathrm{TE}=121 \mathrm{msec}$, MTX $=256 \times 256$. Hyperintense areas on the 9 slices of each $90 \times 90 \mathrm{~mm}$ MRI image was assessed using Image $\mathrm{J}$ analysis software, as previously described [36].

\section{Histological Analysis}

The day after MRI imaging, spinal cord tissue was excised and processed for cresyl violet staining and lesion volume analysis as previously described Byrnes, $2010 \# 3024\}$. Briefly, a $1 \mathrm{~cm}$ section of the spinal cord centered at the lesion epicenter, T9, was dissected and $20 \mu \mathrm{m}$ thick coronal sections were collected and stained with cresyl violet. The Cavalieri method of stereology was used to estimate lesion volume, using a random start section followed by lesion volume measurement, 
including the cavity and surrounding damaged tissue, every $400 \mu \mathrm{m}$.

\section{Statistical Analysis}

Quantitative data are presented as mean +/- standard error of the mean. Lesion volume, western blot, and immunohistochemical data were obtained by an investigator blinded to treatment group. All data were analyzed using Student's $t$ test or one-way ANOVA, where appropriate. All statistical tests were performed using the GraphPad Prism Program, Version 3.02 for Windows (GraphPad Software, San Diego, CA). A $p$ value $<0.05$ was considered statistically significant.

\section{Results}

\section{Spinal cord injury induces long term changes in} expression of microglial-associated genes

Microarray analysis was performed 4 hours, 24 hours, 7 days, 14 days, 28 days, 3 months and 6 months after mild, moderate and severe spinal cord contusion injury at T9. Gene expression data was retrieved from Affymetrix high density oligonucleotide arrays of approximately 24,000 probe sets. Our previous paper [15] detailed the expression of genes associated with microglial function up to 7 days after SCI. Analysis of chronic expression demonstrated additional expression profiles expanding upon the previous data. In this study, anchor gene temporal clustering methods identified two temporally distinct gene clusters with a correlation $r^{2}$ value of greater than 0.98 (Figure 1, Table 1).

The 'acute expression' cluster, identified using the anchor genes COX-2 and Osteopontin displayed a significant increase in expression early after injury, followed by a reduction in expression by day 7 (Figure 1). There were 9 genes found to be temporally correlated within this 'acute expression' cluster (Table 2).

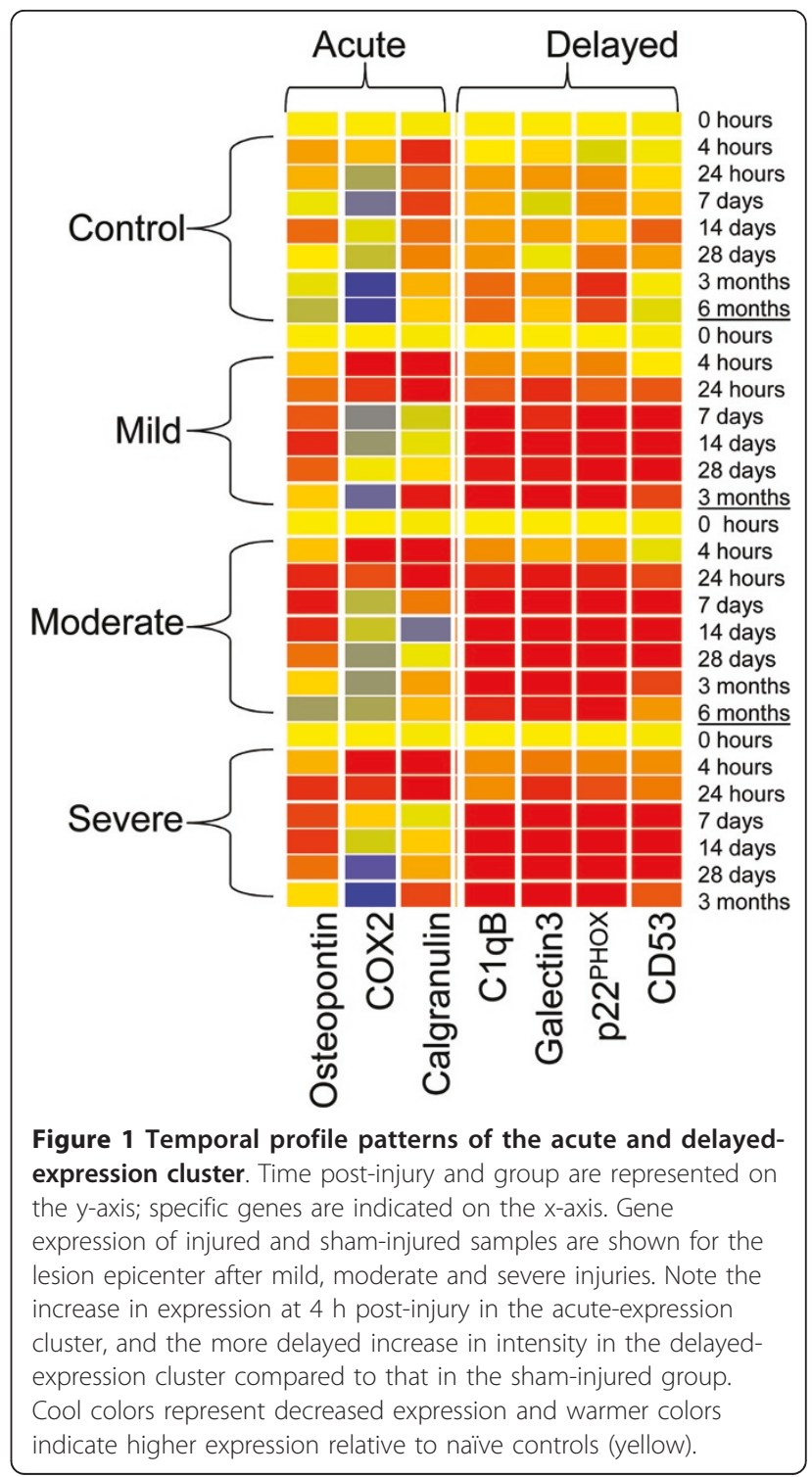

Table 1 Abbreviated gene clusters identified after SCI

\begin{tabular}{|c|c|c|c|c|c|c|c|c|c|c|}
\hline \multirow[t]{2}{*}{ Gene Name } & \multirow[t]{2}{*}{ Description } & \multirow{2}{*}{$\begin{array}{l}\text { GenBank } \\
\text { Accession }\end{array}$} & \multicolumn{8}{|c|}{ Fold Change } \\
\hline & & & $4 \mathrm{hr}$ & $24 \mathrm{hr}$ & $72 \mathrm{hr}$ & $7 d$ & $14 d$ & 28d & $3 \mathrm{mo}$ & $6 \mathrm{mo}$ \\
\hline \multicolumn{11}{|c|}{ Group 1: Acute Expression } \\
\hline $\begin{array}{l}\text { Ptgs2 (COX- } \\
\text { 2) }\end{array}$ & $\begin{array}{l}\text { Anchor Mediator of inflammatory functions, enzymatically } \\
\text { transforms arachidonic acid into prostaglandins }\end{array}$ & S67722 & $2.3^{*}$ & $1.3^{*}$ & 1.7 & 0.9 & 0.6 & 0.9 & $2.9 *$ & $2.0 *$ \\
\hline Osteopontin & Pro-inflammatory cytokine & NM_012881 & 1.6 & $5.0^{*}$ & $4.7^{*}$ & $4.6^{*}$ & 0.9 & 0 & 1.3 & $1.7^{*}$ \\
\hline $\begin{array}{c}\text { S100a8 } \\
\text { (Calgranulin) }\end{array}$ & Calcium binding protein expressed by monocytes & NM_053822 & $5.8^{*}$ & $5.5^{*}$ & $2.8^{*}$ & 0.9 & 0.1 & & 1.3 & 0.9 \\
\hline \multicolumn{11}{|c|}{ Group 2: Delayed Expression } \\
\hline $\mathrm{C} 1 \mathrm{qB}$ & Anchor Component of the complement chain and binds antigen. & x71127 & 0.97 & $2.2^{*}$ & $3.5^{*}$ & $7.1^{*}$ & $5.9 *$ & $7.2 *$ & $2.2 *$ & $1.6 *$ \\
\hline Galectin3 & $\begin{array}{c}\text { Galactose specific lectin that binds lgE and extracellular matrix } \\
\text { proteins. }\end{array}$ & J02962 & $1.5^{*}$ & $2.4^{*}$ & $2.3^{*}$ & $10^{*}$ & $4.4^{*}$ & $12.8^{*}$ & $4.0^{*}$ & $4.0^{*}$ \\
\hline $\mathrm{P} 22 / \mathrm{CYBa}$ & Core component of NADPH Oxidase within phagocytes. & U18729 & 1.1 & $1.9^{*}$ & $2.8^{*}$ & $9.3^{*}$ & $7.8 *$ & $4.4^{*}$ & $1.7 *$ & 1.4 \\
\hline OX44/CD53 & Integral membrane protein that mediates signal transduction & M57276 & 0.9 & $2.2^{*}$ & $3.5^{*}$ & $6.0^{*}$ & $3.8 *$ & $5.3 *$ & $3.2 *$ & $2.1^{*}$ \\
\hline
\end{tabular}


Table 2 Acute Expression Cluster

\begin{tabular}{ll}
\hline Gene Name & GenBank Accession \\
\hline Ptgs2 (COX-2) Anchor & S67722 \\
\hline Osteopontin/SPP1 & NM_012881 \\
\hline S100a8 (Calgranulin) & NM_053822 \\
\hline PGES & Rc_AA944447_at \\
\hline EST220254 & rc_Al176662_s_at \\
\hline EGR1 & M18416_at \\
\hline RGD1564664 & rc_AA945679_s_at \\
\hline LOC500300 & rC_AA858817_at \\
\hline RGD1560812 & rC_Al230381_at
\end{tabular}

Gene name and GenBank Accession number of genes correlated at 0.98 or above. EST or untranscribed sequences have not been included in this list.

The 'delayed expression' cluster, identified using the $\mathrm{C} 1 \mathrm{qB}$ anchor gene, was not up-regulated until 24 to 48 hours after injury, but then remained up-regulated throughout the study, up to 6 months post-injury (Table 1, Figure 1, 2). Expression of genes in this cluster peaked between 7 and 28 days post-injury, and remained elevated in comparison to sham-injured rats through 6 months post-injury. This expression profile was similar regardless of injury severity. Twenty-three genes were found to be temporally correlated, with an $\mathrm{r}^{2}$ value of greater than 0.99 in this cluster (Table 3).

Genes in the 'delayed expression' cluster include genes previously identified [15], including $\mathrm{p} 22^{\mathrm{PHOX}}$, galectin-3, and AIF/MRF, as well as a selection of novel genes, including progranulin and gp $91^{\mathrm{PHOX}}$. These genes showed similar expression profiles, with expression delayed until 7 days post-injury followed by prolonged up-regulation for up to 6 months (Figure 2).

Pathway analysis shows ample connectivity between clustered genes identified in the microarray

To determine connectivity amongst the delayed expression gene cluster, GeneGo's MetaCore ${ }^{\mathrm{TM}}$ software was used to perform a pathway analysis. 'Direct Interaction' algorithm analysis revealed that several genes were

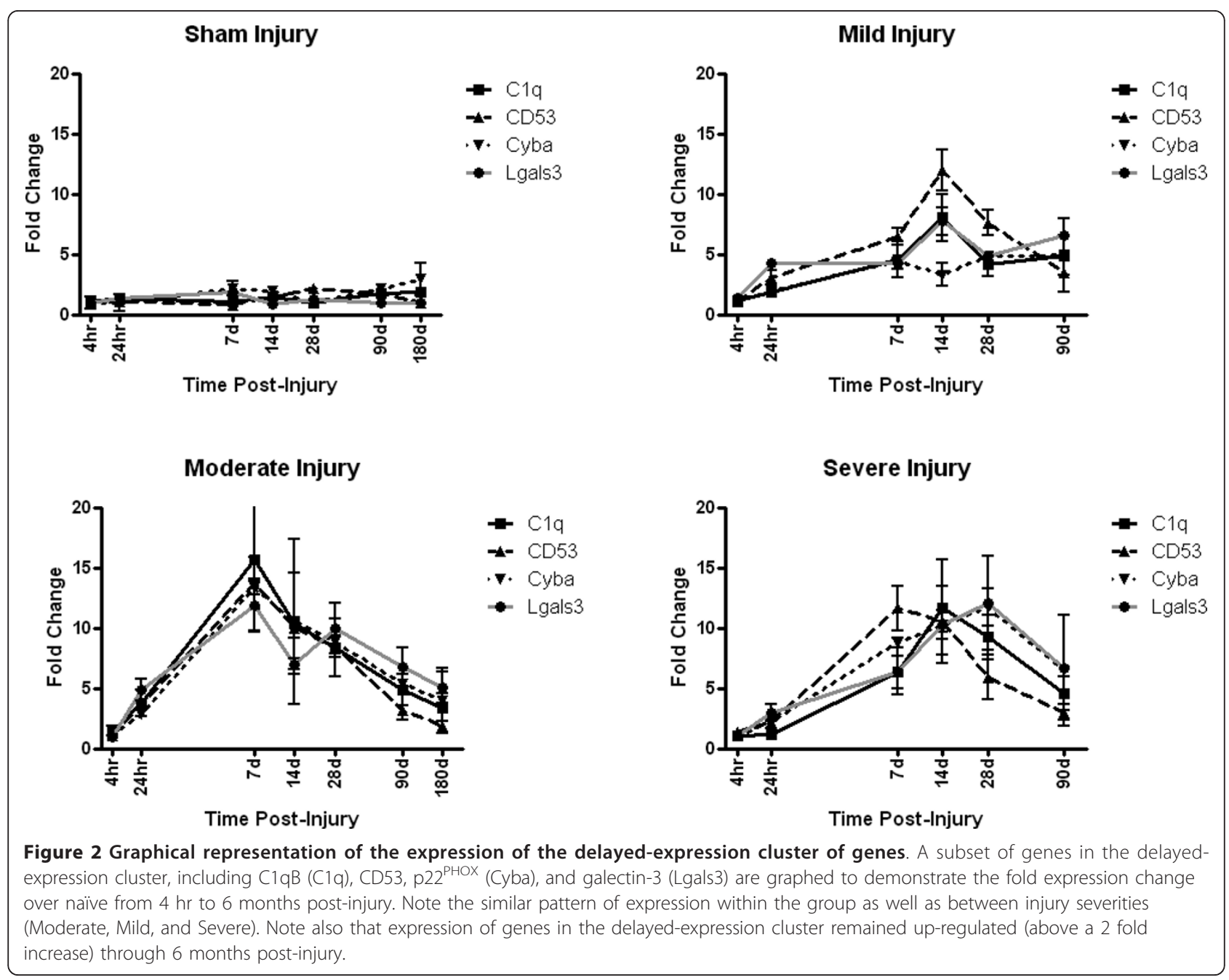


Table 3 Delayed Expression Cluster

\begin{tabular}{|c|c|}
\hline Gene Name & $\begin{array}{l}\text { GenBank } \\
\text { Accession }\end{array}$ \\
\hline $\mathrm{ClqB}$ (Anchor) & $\times 71127$ \\
\hline Fc receptor, IgG, low affinity III & M32062_g_at \\
\hline Glucuronidase, beta & M13962mRNA\#2_at \\
\hline Similar to MS4A6B protein & rC_Al012739_at \\
\hline Galectin 3 & JO2962 \\
\hline $\begin{array}{l}\text { Capping protein (actin filament), gelsolin-like } \\
\text { (predicted) }\end{array}$ & rC_AA894004_at \\
\hline Granulin & X62322_9_at \\
\hline $\mathrm{P} 22 / \mathrm{CYBa}$ & U18729 \\
\hline $\begin{array}{l}\text { Tyro protein tyrosine kinase binding protein } \\
\text { (DAP12) }\end{array}$ & rc_Al102519_at \\
\hline Lysosomal-associated protein transmembrane 5 & rC_AA925353_at \\
\hline CD68 antigen (predicted) & rc_Al177761_at \\
\hline OX44/CD53 & M57276 \\
\hline Similar to carnosinase 1 & rc_Al231438_at \\
\hline Similar to MS4A6B protein & rc_Al012739_at \\
\hline Lymphocyte cytosolic protein 2 & rC_Al060017_at \\
\hline Cytochrome b-245, beta polypeptide (gp91PHOX) & rc_AA894029_at \\
\hline $\begin{array}{l}\text { V-maf musculoaponeurotic fibrosarcoma oncogene } \\
\text { family, protein B (avian) }\end{array}$ & rC_Al169152_at \\
\hline Allograft inflammatory factor 1 & U17919_s_at \\
\hline Acid sphingomyelinase-like phosphodiesterase $3 \mathrm{~A}$ & rc_Al177804_at \\
\hline
\end{tabular}

directly linked. FC $\gamma$ RII $\alpha$ was suggested to directly activate galectin-3 (indicated by a dark green arrow in Figure 3). Moving up by one interaction showed that DAP12 and Slp76 were also directly linked to FC $\gamma$ RII $\alpha$ and galectin-3, through interaction with Zap70, Syk and SHP-1. In addition, CD53 and CD68 were linked through interactions with c-Jun.

Pathways involving the delayed expression genes were further explored using the 'Shortest Path' and 'Transcription Regulation' algorithms. These pathways suggested close interactions amongst the genes on the list, and similar transcriptional regulation (Figure 3). For example, the ETS1 transcription factor was found to be linked to CD68, p22 $2^{\text {PHOX }}$, CD53, and Slip76 (indicated by dark blue arrows in Figure 3). SP1 was directly linked to CD68, BGLR, p $22^{\text {PHOX }}$, CD53 and galectin-3 (indicated by light blue arrows in Figure 3). Similar potential induction pathways were also observed; IFN $\gamma$, for example, was associated with the expression of FC $\gamma$ RII $\alpha$, Slip76 and LAPTM5. Interestingly, pro-inflammatory cytokines were identified as potentially inducing the expression of several genes of the delayed expression list; for example, TNF $\alpha$ and IL1 $\beta$ may induce p $22^{\mathrm{PHOX}}$ and PTX3, which may induce $\mathrm{C} 1 \mathrm{qB}$ expression. Alternatively, anti-inflammatory cytokines were associated with reduced expression of genes in the delayed expression cluster. IL4, for example, reduced FC $\gamma$ RII $\alpha$, CD68, and PTX3 expression. There were also instances within the identified pathways where genes on the list had functions that could induce expression of other genes on the list. For example, DAP12 and FC $\gamma$ RII $\alpha$ were found to be associated with reduced AP1 activity, and reduction of AP1 could potentially increase galectin-3 expression.

\section{Galectin-3 and Progranulin protein expression confirm mRNA profiles}

Galectin-3 and progranulin were selected to confirm that mRNA up-regulation was paralleled by increases in protein expression using western blot and immunohistochemistry at time points from 28 days through 6 months post-injury. western blotting indicated that galectin-3 was significantly increased in injured tissue in comparison to sham-injured tissue at 28 days and 6 months postinjury (Figure 4A, B). This was confirmed with immunolabeling, which demonstrated that galectin-3 was expressed at high levels at 28 days post-injury in round/ ameboid shaped cells, indicative of activated and phagocytic microglia/macrophages (Figure 4C - F). Doublelabel immunohistochemistry was used to confirm expression of proteins of interest in microglia/macrophages and other cell types. Galectin-3 was found to consistently label a large subset of Iba-1 positive cells, indicating microglial/macrophage expression (Figure 4F). No colabeling was found with NeuN or GFAP, indicating that galectin-3 was not expressed in neurons or astrocytes, respectively, at 28 days after SCI (data not shown). While an assessment of the number of Iba-1/galectin-3 positive cells was not done in this study, it was clear that the majority of Iba- 1 positive cells were also galectin- 3 positive, and few galectin- 3 positive cells were identified that were not Iba-1 positive, suggesting that galectin-3 was primarily expressed on microglia/macrophages.

Immunolabeling also confirmed the expression profile observed in the microarray for progranulin (Figure 5A). Progranulin was markedly increased in injured tissue at 28 days post-injury in contrast to sham-injured tissue (Figure 5B). Double-immunolabeling demonstrated that Iba-1 positive microglia/macrophages expressed progranulin (Figure 5C). However, some neurons were also positive for progranulin, as demonstrated by NeuN/progranulin positive cells (Figure 5D). Progranulin was not found in GFAP positive cells, however (data not shown).

\section{NADPH oxidase component expression and activity confirm mRNA expression profiles}

The NADPH oxidase enzyme components $\mathrm{p} 22^{\mathrm{PHOX}}$ and gp91 ${ }^{\text {PHOX }}$ were both identified in the 'delayed expression' cluster. The protein products of these genes make up the membrane-bound components of NADPH oxidase 


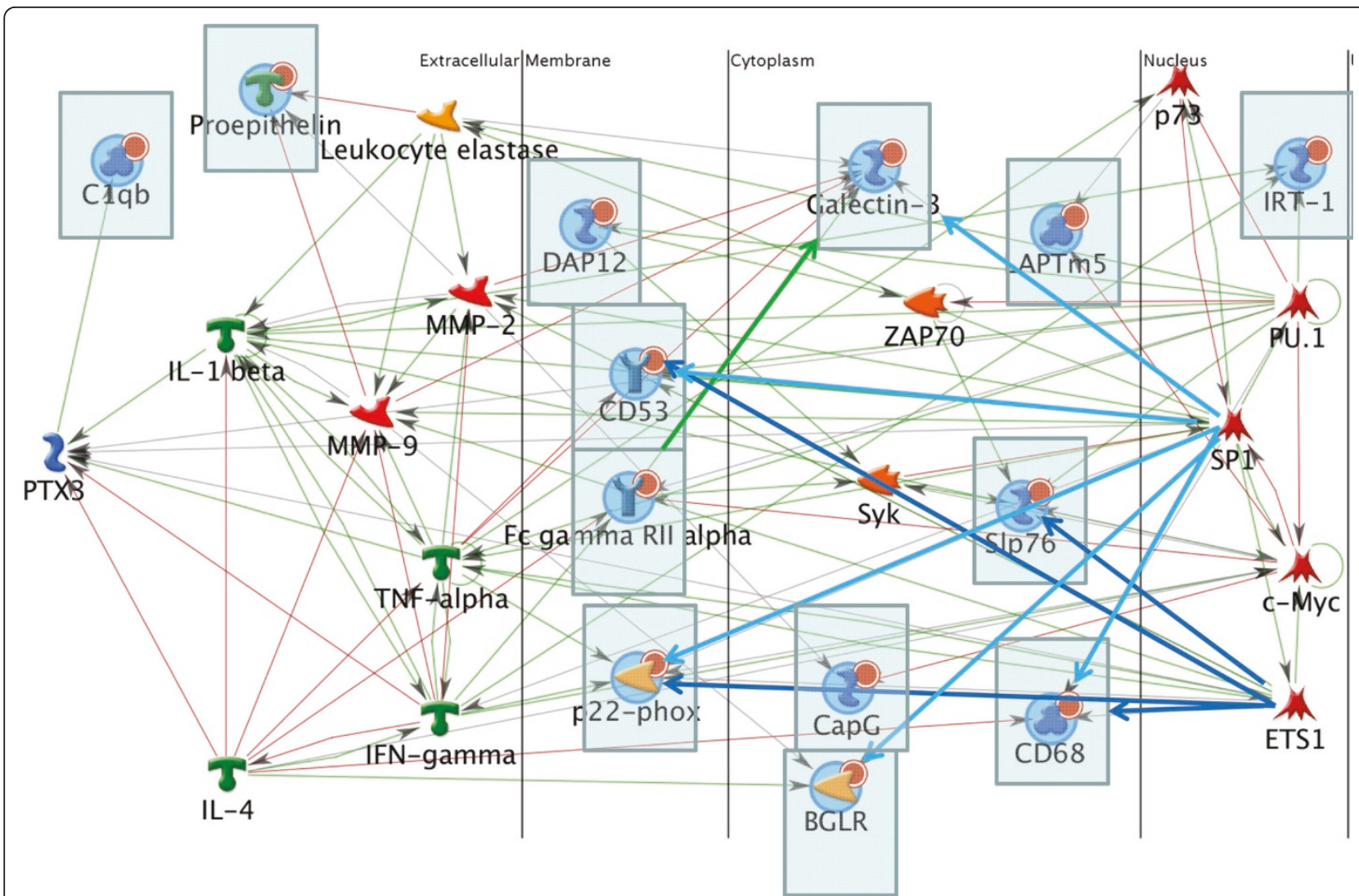

Figure 3 Demonstration of pathway connections amongst genes of the delayed-expression group. The 'Transcriptional Regulation' algorithm demonstrated a high degree of interconnection and pathway similarities amongst genes of the delayed-expression cluster (identified with blue bubbles and highlighted in boxes). Genes are organized according to compartments, with extracellularly located proteins placed on the left of the figure, and nuclear proteins on the right. Note the multiple connections between genes of the delayed-expression cluster and a few transcription factors, including ETS1 and SP1, as well as common induction pathways, such as IFN $\gamma$ and TNF $\alpha$. Green lines indicate positive interactions; red lines indicate negative interactions. Connections of interest, for example between transcription factors and genes of interest and direct interactions, have been highlighted.

enzyme, which is involved in ROS production by phagocytic cells. To confirm that the increase in gene expression is accompanied by an increase in protein expression and functional activity, western blotting, immunohistochemistry and function assays were performed for $\mathrm{p} 22^{\text {PHOX }}$ and gp91 ${ }^{\text {PHOX }}$. Western blot analysis of gp91 ${ }^{\mathrm{PHOX}}$ protein expression at 28 days post-injury indicated an increase in expression in injured tissue compared to sham tissue (Figure 6A). At 6 months postinjury, western blotting demonstrated a significant increase in $\mathrm{p} 22^{\mathrm{PHOX}}$ protein compared to sham, confirming the delayed expression suggested by the mRNA data (Figure 6B). Immunohistochemistry at 28 days postinjury demonstrated an increase in $\mathrm{p} 22^{\mathrm{PHOX}}$ immunolabeling in contrast to sham-injured tissue (Figure 6C).

To confirm that the protein expression was accompanied by an increase in functional activity, NADPH oxidase activity was assessed at 3 and 6 months postinjury. At both time points, NADPH oxidase activity was significantly elevated above sham levels (Figure 7), demonstrating that gene and protein expression is accompanied by functional activity.

\section{Inhibition of NADPH oxidase reduces lesion volume and expression of other proteins in the 'delayed expression cluster'}

Our data has demonstrated that NADPH oxidase expression and activity is chronically up-regulated after SCI. To determine if this enzyme plays a role in chronic expression of microglial-related inflammatory proteins after SCI, particularly those in the 'delayed expression cluster', an inhibitor of NADPH oxidase, DPI [37] was administered continuously for 7 days starting 30 minutes after injury ( $\mathrm{n}=3$ /group). At 28 days post-injury, all rats underwent T2-weighted MRI for assessment of post-injury lesion volume, which we have previously shown to correlate with histological measurements of lesion volume [38]. Vehicle-treated 


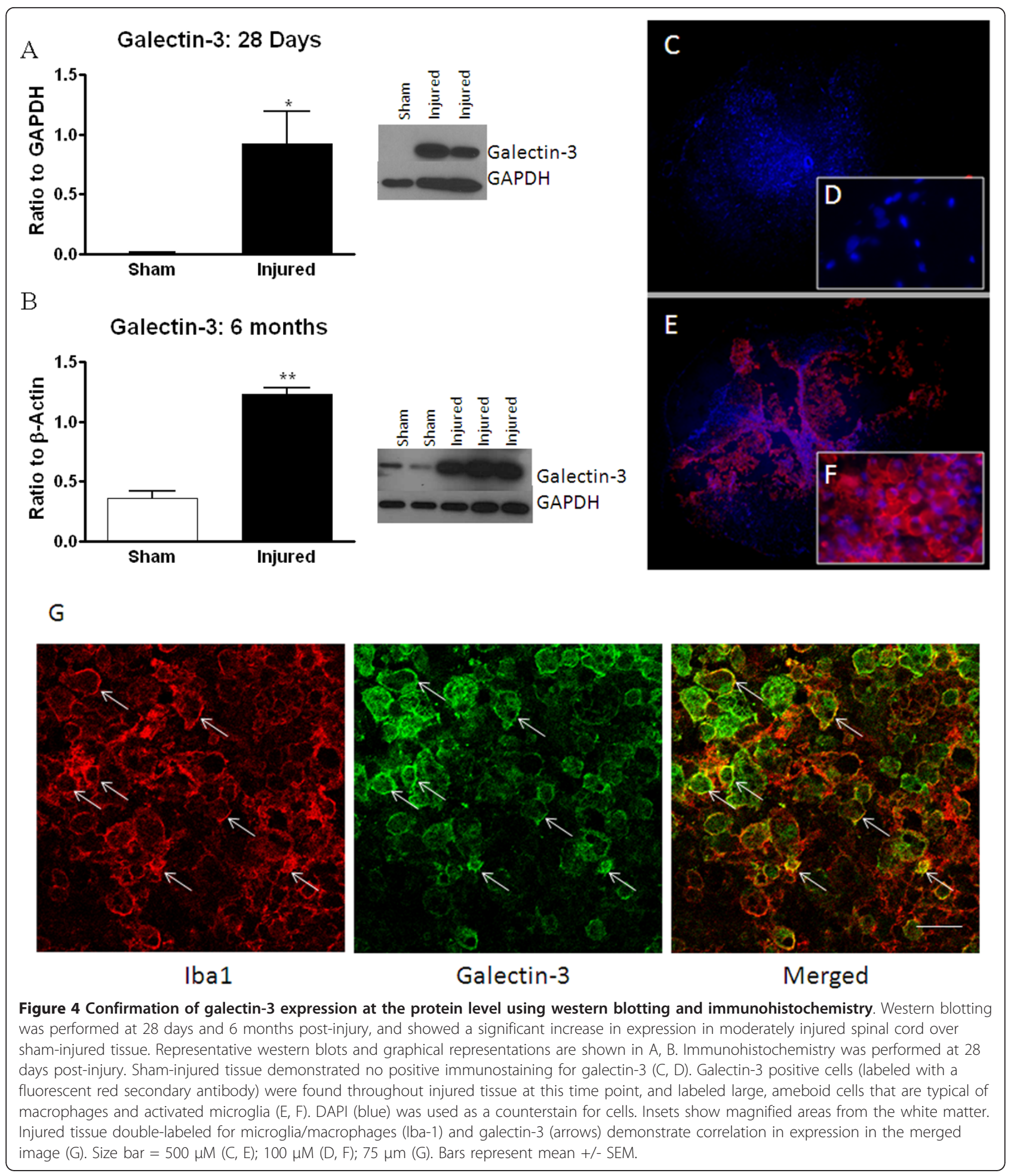

rats had a lesion volume of $0.16+/-0.04 \mathrm{~cm}^{3}$ (Figure 8). A significant reduction in lesion volume was found in rats that received DPI treatment (Figure 8; $0.05+/-0.01 \mathrm{~cm}^{3}$ ). This reduction was confirmed with histology. The day after MRI, tissue was dissected and lesion volume measured in cresyl violet stained sections. Based on histological measurements, DPI-treated spinal cord had significantly $(\mathrm{p}<0.05)$ smaller lesion volume than vehicle-treated spinal cord tissue (Figure 8). 


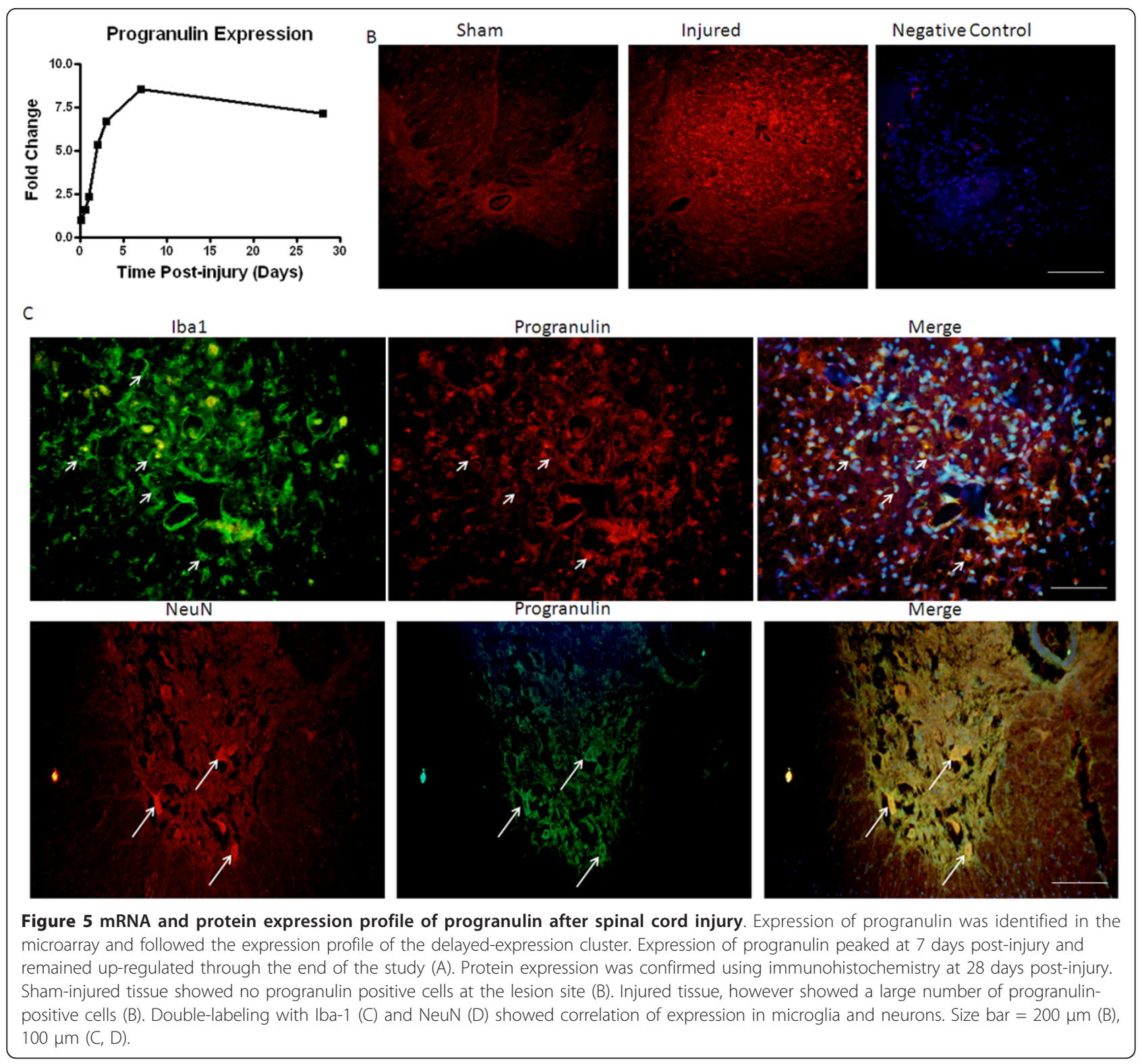

Tissue was then assessed for multiple markers of chronic inflammation 28 days after injury. Immunohistochemistry was performed for the NADPH oxidase component $\mathrm{p} 22^{\mathrm{PHOX}}$ and the chronically expressed inflammatory proteins galectin-3 and progranulin. Immunolabeling for p $22^{\text {PHOX }}$, progranulin and galectin-3 was significantly reduced by DPI treatment (Figure 9). Western blotting further confirmed the reduction of chronically expressed progranulin after DPI treatment, with a significant reduction in expression at 28 days after injury in the treated group in contrast to the vehicle group (Figure 9J).

\section{Discussion}

This work is a continuation and expansion of our previous findings demonstrating the existence of a delayed expression cluster of inflammation-related genes [15]. Here we demonstrate that SCI results in a marked chronic up-regulation of the expression of a cluster of inflammation-related genes. Secondary injury, including chronic demyelination, also lasts for weeks to months after SCI [39]. A recent study by Naphade et al. [40] demonstrated a secondary peak of inflammation as late as 2 months post-injury. It is possible that this chronic inflammatory response may contribute to the continuation of damage in the injured cord.

Further, certain of these genes have been found to be up-regulated in other CNS injury and neurodegenerative models. For example, C1qB expression is increased in areas of demyelination in amyotrophic lateral scleroris (ALS) patients [41]. Both C1qB and galectin-3 are up- 


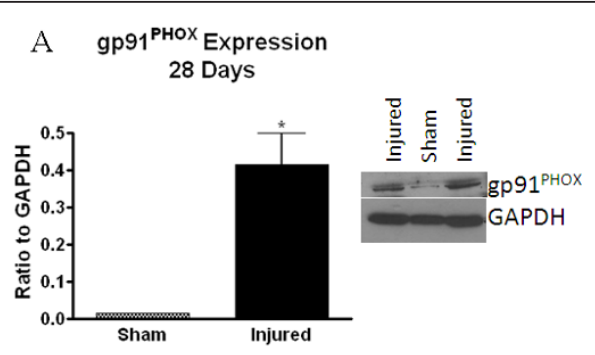

B
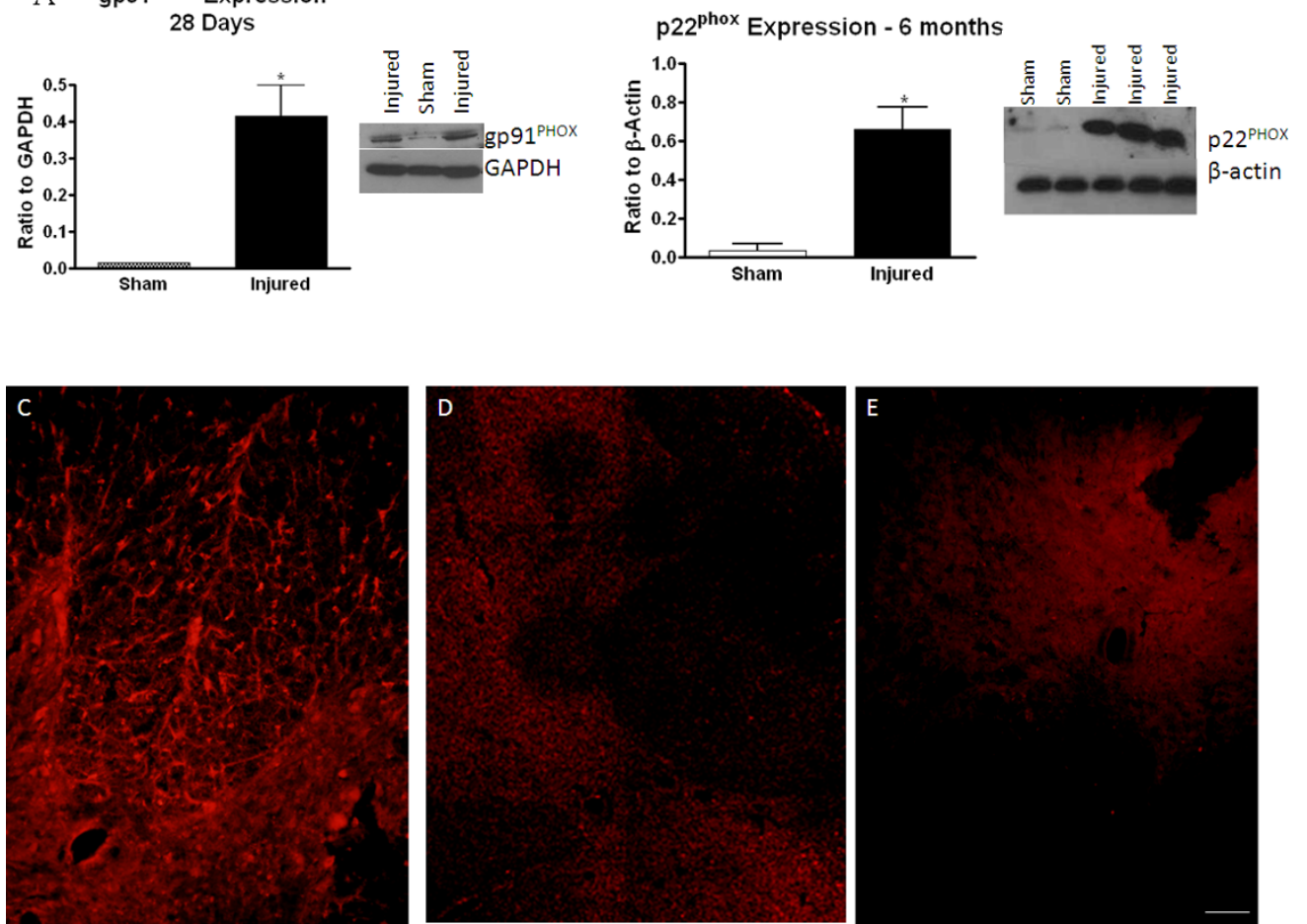

Figure 6 Confirmation of components of the NADPH oxidase enzyme. NADPH oxidase components gp91 ${ }^{\text {PHOX }}(\mathrm{A})$ and $\mathrm{p} 22^{\mathrm{PHOX}}(\mathrm{B})$ were confirmed using western blotting at 28 days and 6 months post-injury. Representative western blots and graphical representation are shown. Bars represent mean +/- SEM. ${ }^{*} p<0.05$. p22 ${ }^{\text {PHOX }}$ expression was also confirmed with immunohistochemistry at 28 days post-injury in injured (C) and sham-injured (D) tissue. No immunolabeling was observed in negative controls where primary antibody was excluded (E), and positive labeling had typical ramified or 'bushy' appearance of microglia/macrophages. Size bar $=100 \mu \mathrm{M}$.

regulated after traumatic brain injury [42]. Galectin-3 has also been shown to be increased after hypoxia/ischemia from 72 hours [43] to at least 2 months post-injury [44]. Progranulin, which has recently been shown to have delayed expression after SCI [40], has also been shown to be increased in microglia in Alzheimer's [45] and ALS disease cases [46].

It is currently unclear if the protein products of the delayed expression cluster play beneficial or detrimental roles after SCI, as recent studies have sparked interest in the pro-inflammatory M1 and anti-inflammatory M2 phenotypes of microglia and macrophages [47]. While the M1/M2 status of cells expressing genes of interest was not explored in this study, it is important to note that many of the genes in the delayed expression cluster can have both advantageous and deleterious effects after injury. For example, progranulin is reportedly associated with both pro- and anti-inflammatory responses, depending upon the availability of the serine protease elastase [45,48]. Elastase is produced by cells of myeloid lineage, such as microglia; in areas with large amounts of elastase, progranulin is cleaved into granulins. Granulins, in turn, can be chemoattractants for macrophages and other inflammatory cells and can induce cytokine production [49,50]. Galectin-3 is also related to both deleterious and regenerative responses after injury. For example, it can directly induce the expression of cytokines, such as IL6 and TNFa [51]. After nerve transection, galectin-3 knockout resulted in significant increases in both the number of regrowing axons and the rate at which function was recovered [52]. Further, knockout of the gene in mice exposed to hypoxia-ischemia reduced white matter loss and markers of apoptosis [43]. However, galectin-3 knockout can reduce phagocytosis, which may impede debris clearance and regeneration [53].

The amount of interaction amongst the genes of the delayed expression cluster is also currently unknown. Interactions have been noted in the literature, including evidence of increased ROS production following C1q or galectin-3 administration to cells [54-56]. Computational pathways analysis revealed that, while there are few direct interactions between genes of the delayed-expression group, these genes may be intimately connected with similar up-stream and down-stream signaling pathways. Common transcription factors may partially explain the similar patterns of up- and down-regulation over time seen within a cluster. In this regard, a small 


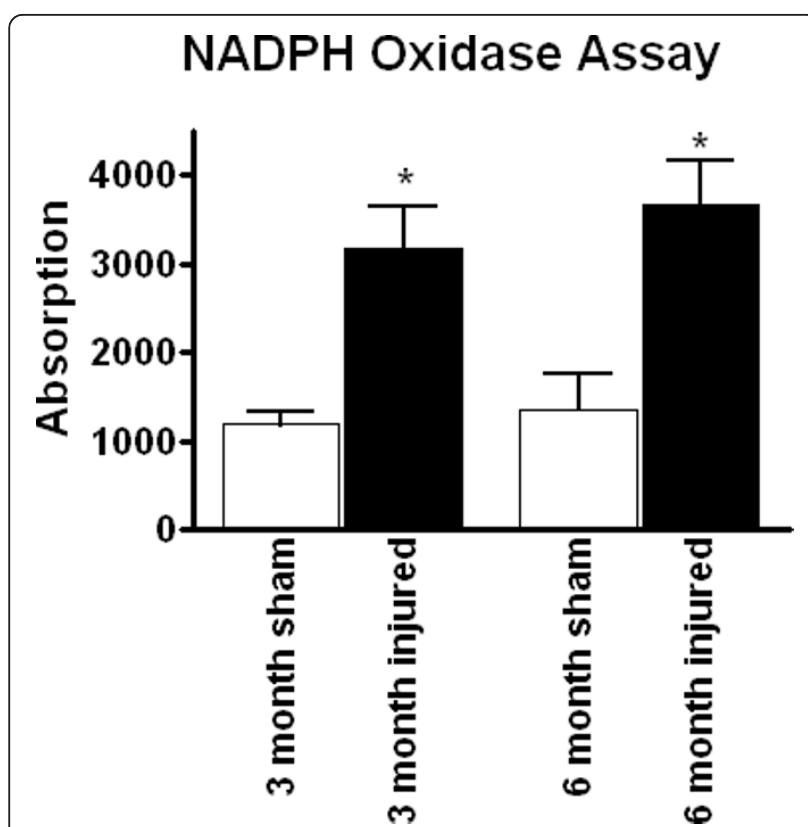

Figure 7 NADPH oxidase enzyme activity profile after spinal cord injury. NADPH oxidase enzyme activity was also assessed to confirm that gene and protein expression translated to enzymatic activity. NADPH oxidase activity was measured in sham and injured spinal cord tissue at 3 and 6 months post-injury. Bars represent mean $+/$ - SEM. * $p<0.05$

group of transcription factors, notably ETS1 and SP1, were associated with many of the genes within the delayed-expression cluster. It is interesting to note that ETS1 and SP1 activity have not been identified previously in SCI models, despite their integral roles in the expression of several components of the inflammatory pathway [57,58], such as NAPDH oxidase components $[59,60]$. It is also possible that this chronic up-regulation of gene expression is a result of stimulation due to a positive feedback loop. For example, it has been shown that transcription factors, such as AP1 and SP1, are sensitive to ROS activation [61]. In fact, knockout of components of the NAPDH oxidase enzyme inhibit AP1 transcriptional activity [62].

Supporting this theory was the finding that DPI administration reduced the expression of progranulin, galectin-3 and $\mathrm{p} 22^{\mathrm{PHOX}}$. Moreover, T2-weighted MRI and histology revealed significantly reduced lesion volume in DPI-treated rats, suggesting that these inflammatory responses may be related to secondary injury and expansion of the lesion site after SCI. Our previous work has demonstrated that there is a significant correlation between MRI-based lesion volume and histological findings [36,38]. These data are in line with previous findings, where administration of apocynin, an alternative NADPH oxidase inhibitor, after transient middle cerebral artery occlusion reduced infarct volume [63].

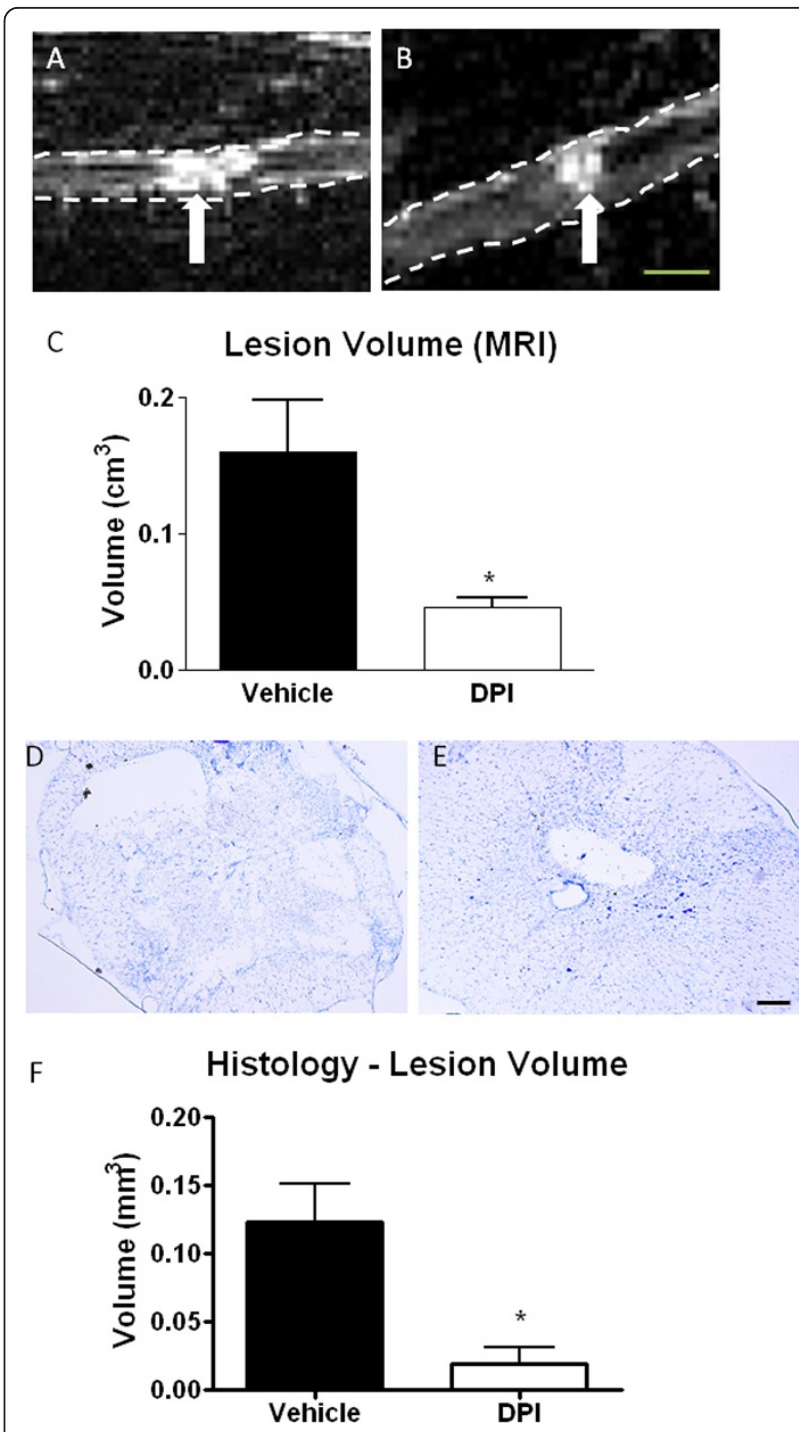

Figure 8 The effect of DPI on lesion volume after spinal cord injury. Lesion volume in vehicle and DPI-treated injured spinal cords was measured at 28 days post-injury using T2-weighted MRI and histology. Representative MRI images of the lesion

(hyperintense region, arrow) are shown for vehicle (A) and DPItreated (B) spinal cords (outlined with dotted line). Representative cresyl violet images are shown for vehicle (D) and DPI-treated (E) spinal cords as well. Quantitation of MRI (C) and histology (F) based measurements are shown. Bar size $=0.25 \mathrm{~cm}(\mathrm{~A}, \mathrm{~B}) ; 200 \mu \mathrm{m}(\mathrm{D}, \mathrm{E})$. Bars represent mean + /- SEM. ${ }^{*} p<0.05 . N=3 /$ group.

Apocynin was also found to limit microglial and astrocytic activity in the hippocampus after ischemia, suggesting reductions in overall inflammatory responses [64]. It is important to note that DPI is a nonspecific inhibitor of NADPH oxidase, and has been shown to have actions on other flavin-containing enzymes. Therefore, future work will explore the effects of more specific NADPH oxidase inhibitors on SCI recovery, including motor functional recovery and axonal preservation. 

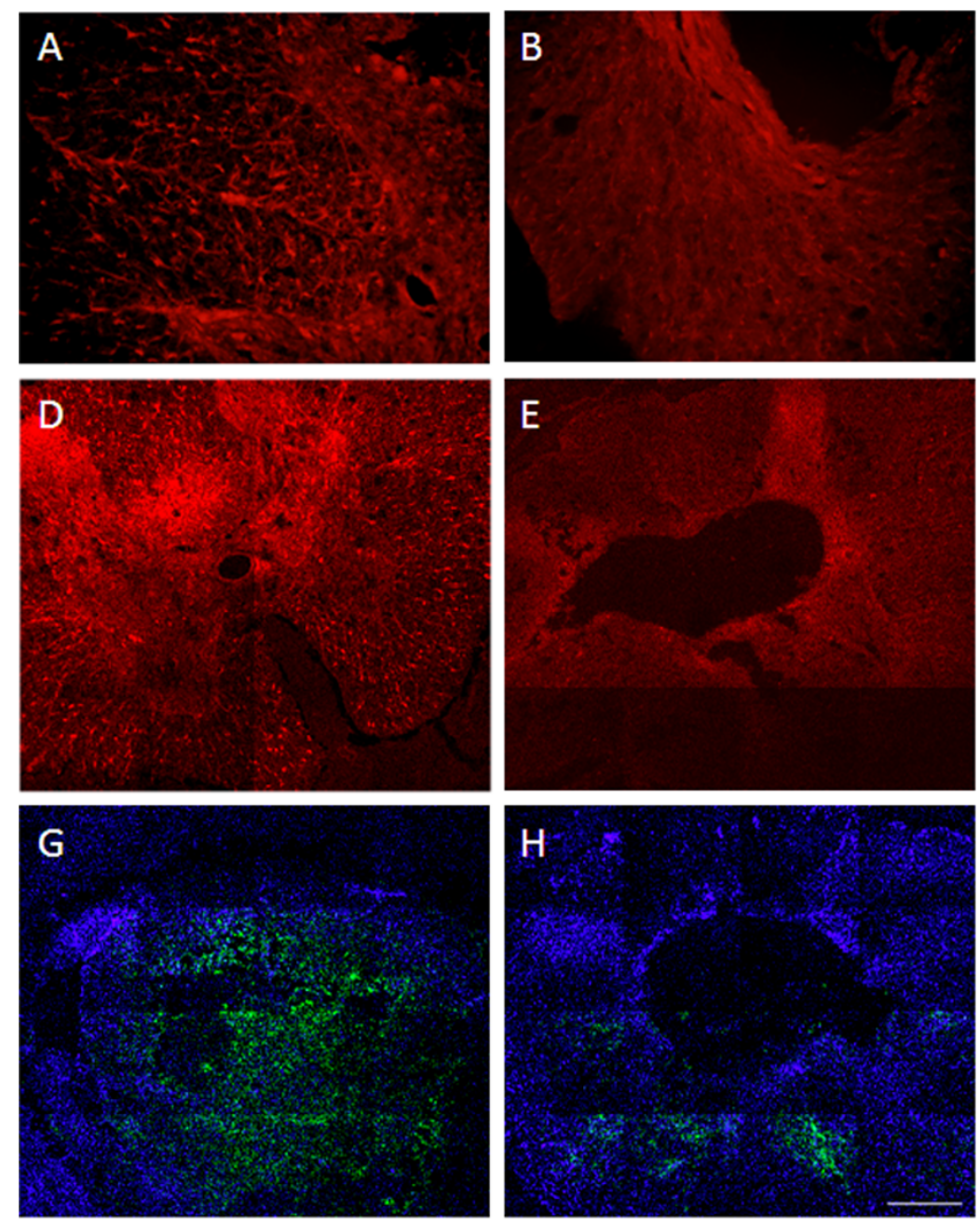

$\mathrm{J}$

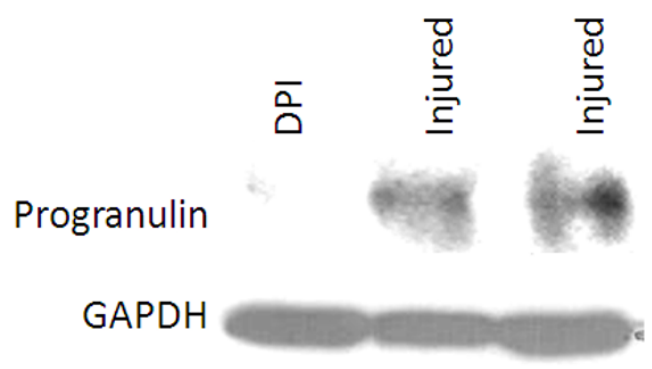

C $\quad$ p22 ${ }^{\text {PHOX }}$

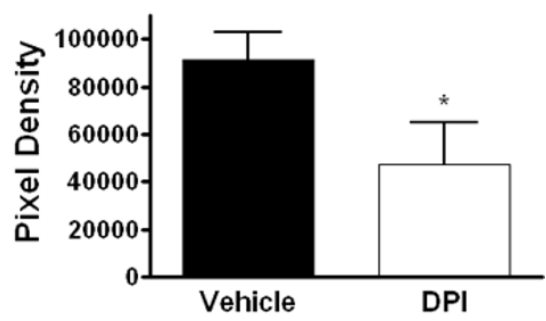

$\mathrm{F}$

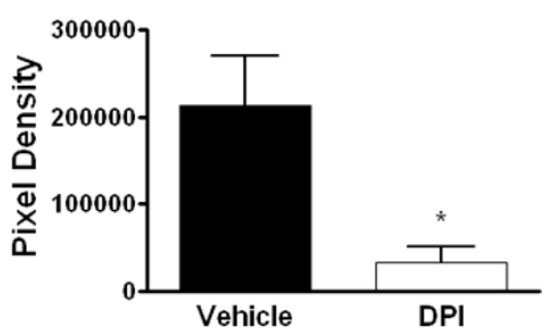

I

\section{Progranulin}

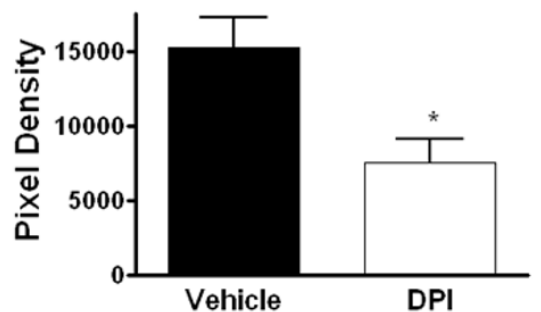

\section{Progranulin}

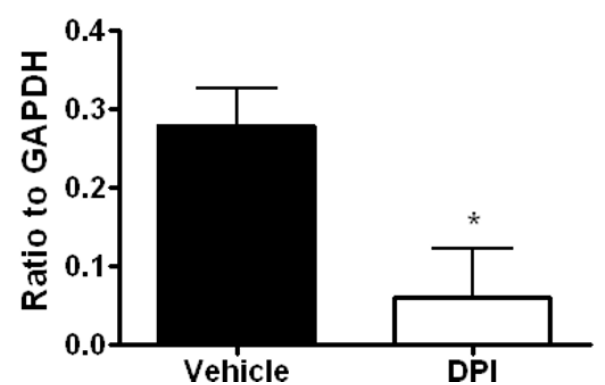

Figure 9 The effect of DPI on inflammatory markers after spinal cord injury. Inflammatory markers were compared in Vehicle (left image) and DPI-treated (right image) spinal cord injured tissue at 28 days post-injury. DPI resulted in significant reductions in p22 ${ }^{\mathrm{PHOX}}$ (red, A, B), progranulin (red, D, E) and galectin-3 (green, G, H) immunolabeling. DAPI-labeled nuclei are shown for contrast in G, H. Immunolabeling was quantified and graphs are shown $(C, F, I)$. Western blotting for progranulin was performed at 28 days post-injury, and revealed a significant decrease in progranulin protein expression in the DPI treated group (J). Representative samples of the western blot are shown. Size bar $=500$ $\mu \mathrm{M}$. Bars represent mean +/- SEM; * $p<0.05$.

In summary, these findings show that $\mathrm{SCI}$ in the rodent is followed by a delayed up-regulation of pro-inflammatory genes that may play a role in secondary injury. These genes are related by similar up-stream regulators, including both transcription factors and inducers. NADPH oxidase, in particular, may play a significant role in propagating chronic expression of these genes, and may serve as a target for therapeutic intervention after SCI. 


\section{List of Abbreviations}

ALS: Amyotrophic Lateral Sclerosis; CDNA: complementary deoxyribonucleic acid; cRNA: complementary ribonucleic acid; Cyba: p22 ${ }^{\mathrm{PHOX}}$; DPI: Diphenylene lodinium; iNOS: inducible nitric oxide synthase; Lgals3: Galectin3; MAPK: Mitogen activated protein kinase; MRI: Magnetic resonance imaging; mRNA: messenger ribonucleic acid; NADPH: Nicotinamide adenine dinucleotide phosphate; NFkB: Nuclear factor k B; ROS: Reactive oxygen species; SCl: Spinal cord injury.

\section{Acknowledgements}

The authors would like to acknowledge Dr. Jorge Garay, Mr. Andrea DeBiase, Ms. Angela Riccio and Ms. Qing Shu for technical support of this project. This project was supported by the National Institutes of Health ( $\mathrm{NIH})$ Grant number R01NS054221-06, and by the NIH IDDRC P30HD40677 and the NIH NCMRR/NINDS 5R24 HD050846 (Integrated Molecular Core for Rehabilitation Medicine).

\section{Author details}

'Department of Neuroscience, Georgetown University Medical Center, Reservoir Rd, NW, Washington, DC (20057), USA. ${ }^{2}$ Department of Anatomy, Physiology and Genetics, Uniformed Services University of the Health Sciences, Jones Bridge Road, Bethesda, MD (20814), USA. ${ }^{3}$ Center for Genetic Medicine, Children's National Medical Center, Michigan Ave, NW, Washington, DC (20010), USA. ${ }^{4}$ Department of Integrative Systems Biology, George Washington University School of Medicine and Health Sciences, I Street NW, Washington, DC (20037), USA. ${ }^{5}$ Department of Anesthesiology, University of Maryland School of Medicine, S. Greene St, Baltimore, MD (21201), USA. ${ }^{6}$ Center for Shock, Trauma and Anesthesiology Research (STAR), University of Maryland School of Medicine, S. Greene St, Baltimore, MD (21201), USA.

\section{Authors' contributions}

$\mathrm{KB}$ carried out or directed the confirmation studies and the DPI study and drafted the manuscript. PW carried out the immunohistochemistry for both the confirmation study and the DPI study. SK carried out the microarray analysis and provided all of the microarray data. EH participated in the design of the study and completion of the microarray analysis. AIF conceived of the study, and participated in its design and coordination and helped to draft the manuscript. All authors read and approved the final manuscript.

\section{Competing interests}

The authors declare that they have no competing interests.

Received: 29 April 2011 Accepted: 5 October 2011 Published: 5 October 2011

\section{References}

1. Dumont RJ, Okonkwo DO, Verma S, Hurlbert RJ, Boulos PT, Ellegala DB, Dumont AS: Acute spinal cord injury, part I: pathophysiologic mechanisms. Clin Neuropharmacol 2001, 24:254-264.

2. Tator $\mathrm{CH}$ : Experimental and clinical studies of the pathophysiology and management of acute spinal cord injury. I Spinal Cord Med 1996, 19:206-214.

3. Fitch MT, Doller C, Combs CK, Landreth GE, Silver J: Cellular and molecular mechanisms of glial scarring and progressive cavitation: In vivo and in vitro analysis of inflammation-induced secondary injury after cns trauma. J Neurosci 1999, 19:8182-8198.

4. Dusart I, Schwab ME: Secondary cell death and the inflammatory reaction after dorsal hemisection of the rat spinal cord. Eur I Neurosci 1994, 6:712-724.

5. Popovich PG, Guan Z, McGaughy V, Fisher L, Hickey WF, Basso DM: The neuropathological and behavioral consequences of intraspinal microglial/macrophage activation. J Neuropathol Exp Neurol 2002, 61:623-633.

6. Teng YD, Choi H, Onario RC, Zhu S, Desilets FC, Lan S, Woodard EJ, Snyder EY, Eichler ME, Friedlander RM: Minocycline inhibits contusiontriggered mitochondrial cytochrome $\mathrm{c}$ release and mitigates functional deficits after spinal cord injury. Proc Natl Acad Sci USA 2004, 101:3071-3076.
7. Stirling DP, Khodarahmi K, Liu J, McPhail LT, McBride CB, Steeves JD, Ramer MS, Tetzlaff W: Minocycline treatment reduces delayed oligodendrocyte death, attenuates axonal dieback, and improves functional outcome after spinal cord injury. J Neurosci 2004, 24:2182-2190.

8. Demjen D, Klussmann S, Kleber S, Zuliani C, Stieltjes B, Metzger C, Hirt UA, Walczak H, Falk W, Essig M, et al: Neutralization of CD95 ligand promotes regeneration and functional recovery after spinal cord injury. Nat Med 2004, 10:389-395.

9. Beattie MS: Inflammation and apoptosis: linked therapeutic targets in spinal cord injury. Trends Mol Med 2004, 10:580-583.

10. Spranger M, Fontana A: Activation of microglia: a dangerous interlude in immune function in the brain. The Neuroscientist 1996, 2:293-305.

11. Gomes-Leal W, Corkill DJ, Freire MA, Picanco-Diniz CW, Perry VH: Astrocytosis, microglia activation, oligodendrocyte degeneration, and pyknosis following acute spinal cord injury. Exp Neurol 2004, 190:456-467.

12. Smith ME, van der Maesen K, Somera FP: Macrophage and microglial responses to cytokines in vitro: phagocytic activity, proteolytic enzyme release, and free radical production. J Neurosci Res 1998, 54:68-78.

13. Davalos D, Grutzendler J, Yang G, Kim JV, Zuo Y, Jung S, Littman DR, Dustin ML, Gan WB: ATP mediates rapid microglial response to local brain injury in vivo. Nat Neurosci 2005, 8:752-758.

14. Popovich PG, Hickey WF: Bone marrow chimeric rats reveal the unique distribution of resident and recruited macrophages in the contused rat spinal cord. J Neuropathol Exp Neurol 2001, 60:676-685.

15. Byrnes KR, Garay J, Di Giovanni S, De Biase A, Knoblach SM, Hoffman EP, Movsesyan V, Faden Al: Expression of two temporally distinct microgliarelated gene clusters after spinal cord injury. Glia 2006, 53:420-433.

16. Popovich PG, Horner PJ, Mullin BB, Stokes BT: A quantitative spatial analysis of the blood-spinal cord barrier. I. Permeability changes after experimental spinal contusion injury. Exp Neurol 1996, 142:258-275.

17. Cross AR, Segal AW: The NADPH oxidase of professional phagocytesprototype of the NOX electron transport chain systems. Biochim Biophys Acta 2004, 1657:1-22.

18. Qin L, Liu Y, Wang T, Wei SJ, Block ML, Wilson B, Liu B, Hong JS: NADPH oxidase mediates lipopolysaccharide-induced neurotoxicity and proinflammatory gene expression in activated microglia. $J \mathrm{Biol}$ Chem 2004, 279:1415-1421.

19. Block ML, Zecca L, Hong JS: Microglia-mediated neurotoxicity: uncovering the molecular mechanisms. Nat Rev Neurosci 2007, 8:57-69.

20. Aldskogius H, Kozlova EN: Central neuron-glial and glial-glial interactions following axon injury. Prog Neurobiol 1998, 55:1-26.

21. Cheret C, Gervais A, Lelli A, Colin C, Amar L, Ravassard P, Mallet J, Cumano A, Krause KH, Mallat M: Neurotoxic activation of microglia is promoted by a nox1-dependent NADPH oxidase. J Neurosci 2008, 28:12039-12051.

22. Peng J, Stevenson FF, Oo ML, Andersen JK: Iron-enhanced paraquatmediated dopaminergic cell death due to increased oxidative stress as a consequence of microglial activation. Free Radic Biol Med 2009, 46:312-320.

23. Gao HM, Jiang J, Wilson B, Zhang W, Hong JS, Liu B: Microglial activationmediated delayed and progressive degeneration of rat nigral dopaminergic neurons: relevance to Parkinson's disease. J Neurochem 2002, 81:1285-1297.

24. Min KJ, Pyo HK, Yang MS, Ji KA, Jou I, Joe EH: Gangliosides activate microglia via protein kinase C and NADPH oxidase. Glia 2004, 48:197-206.

25. Pawate $S$, Shen $Q$, Fan F, Bhat NR: Redox regulation of glial inflammatory response to lipopolysaccharide and interferongamma. J Neurosci Res 2004, 77:540-551.

26. Doussiere J, Gaillard J, Vignais PV: The heme component of the neutrophil NADPH oxidase complex is a target for aryliodonium compounds. Biochemistry 1999, 38:3694-3703.

27. O'Donnell BV, Tew DG, Jones OT, England PJ: Studies on the inhibitory mechanism of iodonium compounds with special reference to neutrophil NADPH oxidase. Biochem J 1993, 290(Pt 1):41-49.

28. Li J, Baud O, Vartanian T, Volpe JJ, Rosenberg PA: Peroxynitrite generated by inducible nitric oxide synthase and NADPH oxidase mediates microglial toxicity to oligodendrocytes. Proc Natl Acad Sci USA 2005, 102:9936-9941.

29. Yakovlev AG, Faden Al: Sequential expression of c-fos protooncogene, TNF-alpha, and dynorphin genes in spinal cord following experimental traumatic injury. Mol Chem Neuropathol 1994, 23:179-190. 
30. Di Giovanni S, Faden Al, Yakovlev A, Duke-Cohan JS, Finn T, Thouin M, Knoblach S, De Biase A, Bregman BS, Hoffman EP: Neuronal plasticity after spinal cord injury: identification of a gene cluster driving neurite outgrowth. Faseb J 2005, 19:153-154.

31. Di Giovanni S, Knoblach SM, Brandoli C, Aden SA, Hoffman EP, Faden Al: Gene profiling in spinal cord injury shows role of cell cycle in neuronal death. Ann Neurol 2003, 53:454-468.

32. Byrnes KR, Stoica BA, Fricke S, Di Giovanni S, Faden Al: Cell cycle activation contributes to post-mitotic cell death and secondary damage after spinal cord injury. Brain 2007, 130:2977-2992

33. Donnelly DJ, Gensel JC, Ankeny DP, van Rooijen N, Popovich PG: An efficient and reproducible method for quantifying macrophages in different experimental models of central nervous system pathology. $J$ Neurosci Methods 2009, 181:36-44.

34. Fernandes DC, Wosniak J Jr, Pescatore LA, Bertoline MA, Liberman M, Laurindo FR, Santos CX: Analysis of DHE-derived oxidation products by HPLC in the assessment of superoxide production and NADPH oxidase activity in vascular systems. Am J Physiol Cell Physiol 2007, 292:C413-422.

35. lannotti C, Ping Zhang Y, Shields CB, Han Y, Burke DA, Xu XM: A neuroprotective role of glial cell line-derived neurotrophic factor following moderate spinal cord contusion injury. Exp Neurol 2004 189:317-332

36. Byrnes KR, Stoica B, Riccio A, Pajoohesh-Ganji A, Loane DJ, Faden Al: Activation of metabotropic glutamate receptor 5 improves recovery after spinal cord injury in rodents. Ann Neurol 2009, 66:63-74.

37. Sorce S, Krause KH: NOX enzymes in the central nervous system: from signaling to disease. Antioxid Redox Signal 2009, 10:2481-504.

38. Byrnes KR, Fricke ST, Faden Al: Neuropathological differences between rats and mice after spinal cord injury. J Magn Res Imag 2010, 32:836-46.

39. Totoiu MO, Keirstead HS: Spinal cord injury is accompanied by chronic progressive demyelination. J Comp Neurol 2005, 486:373-383.

40. Naphade SB, Kigerl KA, Jakeman LB, Kostyk SK, Popovich PG, Kuret J: Progranulin expression is upregulated after spinal contusion in mice. Acta Neuropathol 2010, 119:123-133.

41. Grewal RP, Morgan TE, Finch CE: C1qB and clusterin mRNA increase in association with neurodegeneration in sporadic amyotrophic lateral sclerosis. Neurosci Lett 1999, 271:65-67.

42. Natale JE, Ahmed F, Cernak I, Stoica B, Faden Al: Gene expression profile changes are commonly modulated across models and species after traumatic brain injury. J Neurotrauma 2003, 20:907-927.

43. Doverhag C, Hedtjarn M, Poirier F, Mallard C, Hagberg H, Karlsson A, Savman K: Galectin-3 contributes to neonatal hypoxic-ischemic brain injury. Neurobiol Dis 2010, 38:36-46.

44. Yan YP, Lang BT, Vemuganti R, Dempsey RJ: Galectin-3 mediates postischemic tissue remodeling. Brain Res 2009, 1288:116-124.

45. Ahmed Z, Mackenzie IR, Hutton ML, Dickson DW: Progranulin in frontotemporal lobar degeneration and neuroinflammation. $J$ Neuroinflammation 2007, 4:7.

46. Philips T, De Muynck L, Thu HN, Weynants B, Vanacker P, Dhondt J, Sleegers K, Schelhaas HJ, Verbeek M, Vandenberghe R, et al: Microglial upregulation of progranulin as a marker of motor neuron degeneration. J Neuropathol Exp Neurol 2010, 69:1191-1200.

47. Kigerl KA, Gensel JC, Ankeny DP, Alexander JK, Donnelly DJ, Popovich PG: Identification of two distinct macrophage subsets with divergent effects causing either neurotoxicity or regeneration in the injured mouse spinal cord. J Neurosci 2009, 29:13435-13444.

48. Yin F, Banerjee R, Thomas B, Zhou P, Qian L, Jia T, Ma X, Ma Y, ladecola C, Beal MF, et al: Exaggerated inflammation, impaired host defense, and neuropathology in progranulin-deficient mice. J Exp Med 2010, 207:117-128, S111-114.

49. Pickford F, Marcus J, Camargo LM, Xiao Q, Graham D, Mo JR, Burkhardt M, Kulkarni V, Crispino J, Hering H, Hutton M: Progranulin is a chemoattractant for microglia and stimulates their endocytic activity. Am J Pathol 2011, 178:284-295.

50. Youn BS, Bang SI, Kloting N, Park JW, Lee N, Oh JE, Pi KB, Lee TH, Ruschke K, Fasshauer M, et al: Serum progranulin concentrations may be associated with macrophage infiltration into omental adipose tissue. Diabetes 2009, 58:627-636.

51. Filer A, Bik M, Parsonage GN, Fitton J, Trebilcock E, Howlett K, Cook M, Raza K, Simmons DL, Thomas AM, et al: Galectin 3 induces a distinctive pattern of cytokine and chemokine production in rheumatoid synovial fibroblasts via selective signaling pathways. Arthritis Rheum 2009, 60:1604-1614

52. Narciso MS, Mietto Bde S, Marques SA, Soares CP, Mermelstein Cdos S, ElCheikh MC, Martinez AM: Sciatic nerve regeneration is accelerated in galectin-3 knockout mice. Exp Neurol 2009, 217:7-15.

53. Dhirapong A, Lleo A, Leung P, Gershwin ME, Liu FT: The immunological potential of galectin-1 and -3. Autoimmun Rev 2009, 8:360-363.

54. Goodman EB, Tenner AJ: Signal transduction mechanisms of C1qmediated superoxide production. Evidence for the involvement of temporally distinct staurosporine-insensitive and sensitive pathways. $J$ Immunol 1992, 148:3920-3928.

55. Karlsson A, Follin P, Leffler H, Dahlgren C: Galectin-3 activates the NADPHoxidase in exudated but not peripheral blood neutrophils. Blood 1998, 91:3430-3438.

56. Fernandez GC, llarregui JM, Rubel CJ, Toscano MA, Gomez SA, Bompadre MB, Isturiz MA, Rabinovich GA, Palermo MS: Galectin-3 and soluble fibrinogen act in concert to modulate neutrophil activation and survival. Involvement of alternative MAPK-pathways. Glycobiology 2005, 15:519-27

57. Lee JH, Woo JH, Woo SU, Kim KS, Park SM, Joe EH, Jou I: The 15-deoxydelta 12,14-prostaglandin J2 suppresses monocyte chemoattractant protein-1 expression in IFN-gamma-stimulated astrocytes through induction of MAPK phosphatase-1. J Immunol 2008, 181:8642-8649.

58. Olefsky JM, Glass CK: Macrophages, inflammation, and insulin resistance. Annu Rev Physiol 2010, 72:219-246.

59. Ni W, Zhan Y, He H, Maynard E, Balschi JA, Oettgen P: Ets-1 is a critical transcriptional regulator of reactive oxygen species and p47(phox) gene expression in response to angiotensin II. Circ Res 2007, 101:985-994.

60. Dusi S, Donini M, Lissandrini D, Mazzi P, Bianca VD, Rossi F: Mechanisms of expression of NADPH oxidase components in human cultured monocytes: role of cytokines and transcriptional regulators involved. Eur J Immunol 2001, 31:929-938.

61. Oh YT, Lee JY, Yoon H, Lee EH, Baik HH, Kim SS, Ha J, Yoon KS, Choe W Kang I: Lipopolysaccharide induces hypoxia-inducible factor-1 alpha mRNA expression and activation via NADPH oxidase and Sp1dependent pathway in BV2 murine microglial cells. Neurosci Lett 2008 431:155-160

62. Wu F, Tyml K, Wilson JX: iNOS expression requires NADPH oxidasedependent redox signaling in microvascular endothelial cells. J Cell Physiol 2008, 217:207-214.

63. Tang XN, Cairns B, Cairns N, Yenari MA: Apocynin improves outcome in experimental stroke with a narrow dose range. Neuroscience 2008 , 154:556-562.

64. Wang Q, Tompkins KD, Simonyi A, Korthuis RJ, Sun AY, Sun GY: Apocynin protects against global cerebral ischemia-reperfusion-induced oxidative stress and injury in the gerbil hippocampus. Brain Res 2006, 1090:182-189.

doi:10.1186/1742-2094-8-130

Cite this article as: Byrnes et al:: Delayed inflammatory mRNA and protein expression after spinal cord injury. Journal of Neuroinflammation $20118: 130$.

\section{Submit your next manuscript to BioMed Central and take full advantage of:}

- Convenient online submission

- Thorough peer review

- No space constraints or color figure charges

- Immediate publication on acceptance

- Inclusion in PubMed, CAS, Scopus and Google Scholar

- Research which is freely available for redistribution

Submit your manuscript at www.biomedcentral.com/submit
C Biomed Central 